\title{
15. INTRASLOPE BASIN INTRODUCTION AND SUMMARY ${ }^{1}$
}

\author{
Shipboard Scientific Party ${ }^{2}$
}

\section{INTRODUCTION}

The continental slope off Louisiana and east Texas is characterized by a large-scale relief topography that is caused by underlying diapirs (Fig. 1). Most of these diapirs are assumed to be the result of diapiric intrusion of salt of Louann age (Middle and Upper Jurassic) and to be overlain by Tertiary sediments (Martin and Bouma, 1978; Martin, 1978). Locally the salt may outcrop or be very near the water/sediment interface. Typically, no two adjacent diapirs are the same size or shape (Martin, 1980) or have the same characteristics regarding the overlying sediments (Bouma, 1983).

The depressions between the diapirs-called intraslope basins-also vary in size, depth, and shape. The utilization of seismic stratigraphy, aided by the collection of piston and gravity cores, has provided a tentative classification of these intraslope basins into three major types: (1) blocked-canyon intraslope basins, (2) interdomal basins, and (3) collapse basins (Bouma et al., 1981).

A blocked-canyon intraslope basin is formed by blockage of the thalweg of a submarine channel caused by upward-moving diapirs. The sediments in the axis of such a basin are assumed to contain "coarse" material that laterally grades into clays along the sides of the diapirs. Well-published examples are Gyre Basin and Pigmy Ba-

\footnotetext{
${ }^{1}$ Bouma, A. H., Coleman, J. M., Meyer, A. W., et al., Init. Repts. DSDP, 96: Washington (U.S. Govt. Printing Office),

2 Addresses: Arnold H. Bouma (Co-Chief Scientist), Gulf Research and Development Company, P.O. Box 37048, Houston, TX 77236, (present address: Chevron Oil Field Research Company, P.O. Box 36506, Houston, TX 77236); James M. Coleman (Co-Chief Scientist), Coastal Studies Institute, Louisiana State University, Baton Rouge, LA 70803; Audrey W. Meyer (Shipboard Science Representative), Deep Sea Drilling Project, Scripps Institution of Oceanography, La Jolla, CA 92093, (present address: Ocean Drilling Program, 500 University Drive West, Texas A\&M University, College Station, TX 77843); James Brooks, Department of Oceanography, Texas A\&M University, College Station, TX 77843; William R. Bryant, Department of Oceanography, Texas A\&M University, College Station, TX 77843; Richand Constans, Paleontology Section, Chevron US. A. Ine, 935 Gravier Street, New Orleans, 70112; ;ichel Cremer deaux I, Avenue des Facultés, 33405 Talence Cedex, France; Laurence I. Droz, Laboratoire de Géodynamique Sous-Marine, 06230 Villefranche-sur-Mer, France; Toshio Ishizuka, Ocean Research Institute, University of Tokyo, Tokyo 164, Japan; Mahlon C. Kennicutt II, Department of Oceanography, Texas A\&M University, College Station, TX 77843; Barry Kohl, Cheyron U.S.A. Inc., 935 Gravier Street, New Orleans, LA 70112; William R. Normark, Pacific Branch of Marine Geology, U.S. Geological Survey (MS-999), 345 Middlefield Road, Menlo Park, CA 94025; Suzanne O'Connell, Lamo Drive West, Texas A M University, College Station, TX 77843); Mary Parker, Departivert Drive West, Texas A\&M University, College Station, TX 77843); Mary Parker, Department of Geology, Florida State University, Tallahassee, FL 32306, (present address: AMOCO Production Company, P.O. Box 50879, New Orleans, LA 70150); Kevin T. Pickering, Department of Earth Sciences, University of London, Goldsmith's College, London SE $146 \mathrm{NW}$, United Kingdom; (present address: Department of Geology, University of Leicester, Leicester LE 7RH, United Kingdom); Claudia Schroeder, Department of Geology, Dalhousie University, Halifax, Nova Scotia B3H 3J5, Canada; Charles E. Stelting. Gulf Research and Development Company, P.O. Box 37048, Houst, TX 77236, (present address: Chevron Oil Field ReCompar search Company, P.O. Box 36506, Houston, TX 7 , inburgh, Edinburgh EH9 3JW, Scotland, United Kingdom, (present address: Geology Department, University of Nottingham, Nottingham NG7 2RD, United Kingdom); William E. Sweet, Mineral Management Service, P.O. Box 7944, Metairie, LA 77010; Andreas Wetzel, Geologisches Palaeontologisches Institut der Universität, Sigwartstrasse 10, D7400 Tübingen, Federal Republic of Germany; and Jean K. Whelan, Chemistry Department, Woods Hole Oceanographic Institution, Woods Hole, MA 02543.
}

sin (Fig. 2); both show acoustical sequences believed to be typical for this type of basin (Fig. 3) (Bouma, 1981, 1982, 1983) (see Site 619 chapter and Bouma, Stelting, et al., this volume).

An interdomal basin forms when a group of upwardmoving diapirs coalesce, thereby forming a depression that is completely surrounded by bathymetric highs and eliminating any possibility of introduction of coarser grained sediments via bottom transport. As a result, only hemipelagic and pelagic sediment can accumulate. Orca Basin (Fig. 4) is the only known example of this category of intraslope basin. This basin is exceptional in that it contains a hypersaline, anoxic layer of bottom water about $200 \mathrm{~m}$ thick (Trabant and Presley, 1978). Seismically outcropping salt can be observed on multichannel records on the northeast side of the basin (Bouma, 1983). Minisparker and air-gun records do not show sub-bottom reflectors that may indicate the thickness of the anoxic bottom sediments or a contact with underlying, older deposits.

Collapse basins are small, irregularly shaped, depressions commonly found over diapiric highs. Collapse basins are the smallest of the three types of intraslope basins. They are either formed by tensional collapse of the overburden or result from vertical collapse because of solution of salt from the top of the diapir (Martin and Bouma, 1978; Bouma et al., 1980; Bouma, 1982, 1983). The sediments are typically hemipelagic and pelagic. Acoustic reflections show thin, parallel reflectors, often disturbed by growth faults and normal faults. Studied examples are Carancahua and East Breaks basins (Bouma et al., 1981).

Scientific objectives for drilling one example of each of the two most important types of intraslope basins were

1. To obtain a complete stratigraphic record of the upper Pleistocene,

2. To establish the organic and inorganic characteristics of the anoxic bottom sediments in Orca Basin and study the vertical interaction of anoxic zones with the incorporated and underlying oxic zones,

3. To establish the thickness of the anoxic sediments in Orca Basin and its age as a vehicle to study the latest upward motion of its surrounding salt diapirs,

4. To qualify and quantify lithologically the nature of the acoustical sequence in blocked-canyon intraslope basins, and

5. To relate the lithologic and acoustic sequence to sea level variations, climatic zones, and sediment transport processes.

Site 619 was drilled in Pigmy Basin, a blocked-canyon basin; Site 618 was drilled in Orca Basin, an inter- 


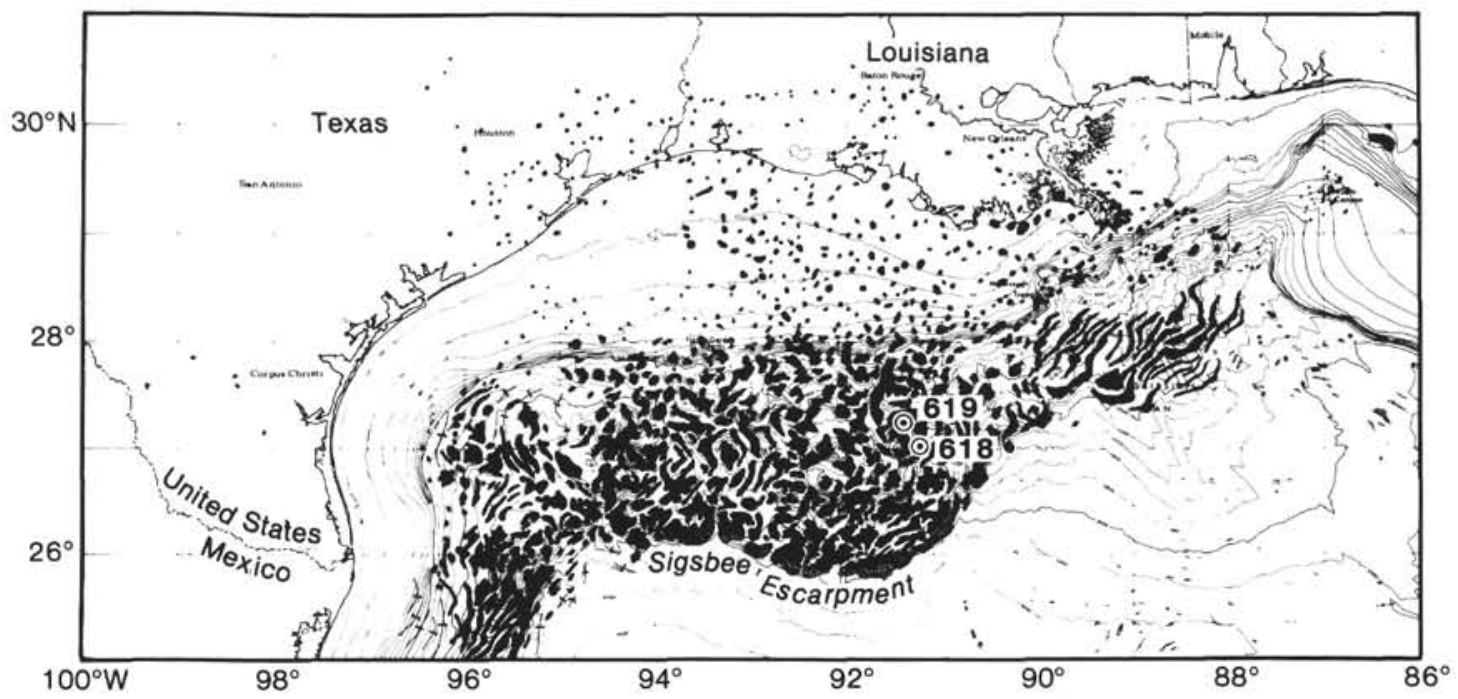

Figure 1. Outline of diapirs at 1-s depth below mud line (from Martin, 1980) and locations of Sites 618 and 619.

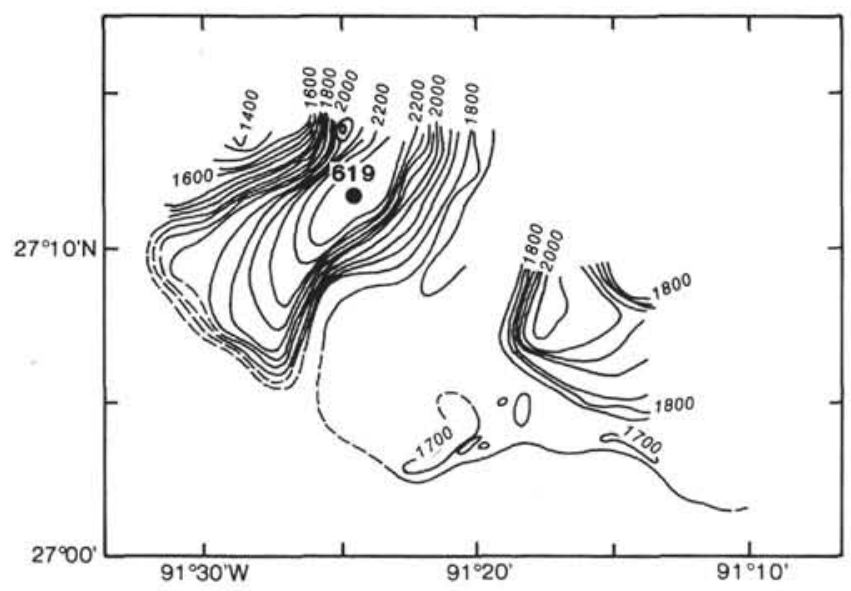

Figure 2. Bathymetric map of the Pigmy Basin area in meters (Feeley, 1982). Contour interval is $50 \mathrm{~m}$.

domal basin which contains a 200 -m-thick hypersaline, anoxic layer of bottom water.

\section{SUMMARY}

The main stratigraphic and geochemical objectives intended for Site 618 were not met because the upper part of the section consists of mass-movement deposits. However, the stratigraphic objectives were realized at Site 619. Drilling in the intraslope basins provided the following main conclusions:

1. The late Pleistocene fill in Pigmy Basin consists primarily of pelagic and hemipelagic sediments with only minor interruptions by localized mass-movement deposits.

2. A well-preserved and rather complete biostratigraphic section of the Wisconsin was cored in Pigmy Basin. Ericson's Zones Z, Y, and X (and W?) were penetrated (see Explanatory Notes, this volume). Computed sedimentation rates were $41.7 \mathrm{~cm} / 1000 \mathrm{yr}$. for the Holocene (Zone Z, $5 \mathrm{~m}$ thick), $194.5 \mathrm{~cm} / 1000 \mathrm{yr}$. for the late Wis- consin glacial (Zone $\mathrm{Y}, 142 \mathrm{~m}$ thick), and $23.8 \mathrm{~cm} / 1000$ yr. for the Wisconsin interstadial (Zone $\mathrm{X}, 10 \mathrm{~m}$ thick).

3. A prominent ash layer was cored in Pigmy Basin at a sub-bottom depth of $141.5 \mathrm{~m}$, above the top of Ericson's Zone X. This is the Y8 ash (Kennett and Huddlestun, 1972), dated at 84,000 yr. before present (Ledbetter, this volume).

4. A good correlation was observed in Pigmy Basin between lithologic units and seismic reflectors (Bouma, Stelting, et al., this volume).

5. Biogenic methane was encountered throughout the entire cored interval in Orca Basin, ranging from $17 \%$ at the surface to $96 \%$ at $90-\mathrm{m}$ sub-bottom depth.

6. Thin zones of white crystalline gas hydrate were cored in the upper sediments of Orca Basin between about 19 and $47 \mathrm{~m}$ sub-bottom (Pflaum et al., this volume).

7. The presence of gas thoroughly disturbed the Site 618 cores, masking the sedimentary structures and precluding an assessment of the sediment transport processes at that site.

8. Interstitial water salinity in Orca Basin decreased from $237 \%$ in the surface core to an average of about $50 \%$ at $30-\mathrm{m}$ sub-bottom depth and then remained rather constant to total drilling depth.

\section{REFERENCES}

Bouma, A. H., 1981. Depositional sequences in clastic continental slope deposits, Gulf of Mexico. Geo-Mar. Lett., 1:105-110.

Bouma, A. H., 1982. Submarine canyon-fan systems in a diapirically controlled area, Gulf of Mexico. Bull. Inst. Geol. Bassin Aquitaine, 31:111-125.

Bouma, A. H., 1983. Intraslope basins in northwest Gulf of Mexico: a key to ancient submarine canyons and fans. Am. Assoc. Pet. Geol. Spec. Publ., 32:567-581.

Bouma, A. H., Martin, R. G., and Bryant, W. R., 1980. Shallow structure of upper continental slope, central Gulf of Mexico. Proc. Annu. Offshore Technol. Conf., 3913:583-592.

Bouma, A. H., et al., 1981. Seismic stratigraphic characteristics of upper Louisiana continental slope: an area east of Green Canyon. Proc. Annu. Offshore Technol. Conf., 4098:283-292.

Feeley, M. H., 1982. Structural and depositional relationships of intraslope basins, northern Gulf of Mexico [M.S. thesis]. Texas A \& M University, College Station. 
Kennett, J. P., and Huddlestun, P., 1972. Late Pleistocene paleoclimatology, foraminiferal biostratigraphy and tephrochronology, western Gulf of Mexico. Quat. Res., 2:38-69.

Martin, R. G., 1978. Northern and eastern Gulf of Mexico continental margin: stratigraphic and structural framework. In Bouma, A. H., Moore, G. T., and Coleman, J. M. (Eds.), Framework, Facies, and Oil-Trapping Characteristics of the Upper Continental Margin. Am. Assoc. Pet. Geol. Stud. Geol., 7:21-42.

Martin, R. G., 1980. Distribution of salt structures in Gulf of Mexico region: map and descriptive text. U.S. Geol. Surv. Misc. Field Stud. Map MF-1213, 8 p., 2 sheets.
Martin, R. G., and Bouma, A. H., 1978. Physiography of the Gulf of Mexico. In Bouma, A. H., Moore, G. T., and Coleman, J. M. (Eds.), Framework, Facies, and Oil-Trapping Characteristics of the Upper Continental Margin. Am. Assoc. Pet. Geol. Stud. Geol., 7: 3-19.

Trabant, P. K., and Presley, B. J., 1978. Orca Basin, anoxic depression on the continental slope, northwest Gulf of Mexico. In Bouma, A. H., Moore, G. T., and Coleman, J. M. (Eds.), Framework, Facies, and Oil-Trapping Characteristics of the Upper Continental Margin. Am. Assoc. Pet. Geol. Stud. Geol., 7:303-311. 
E

0000

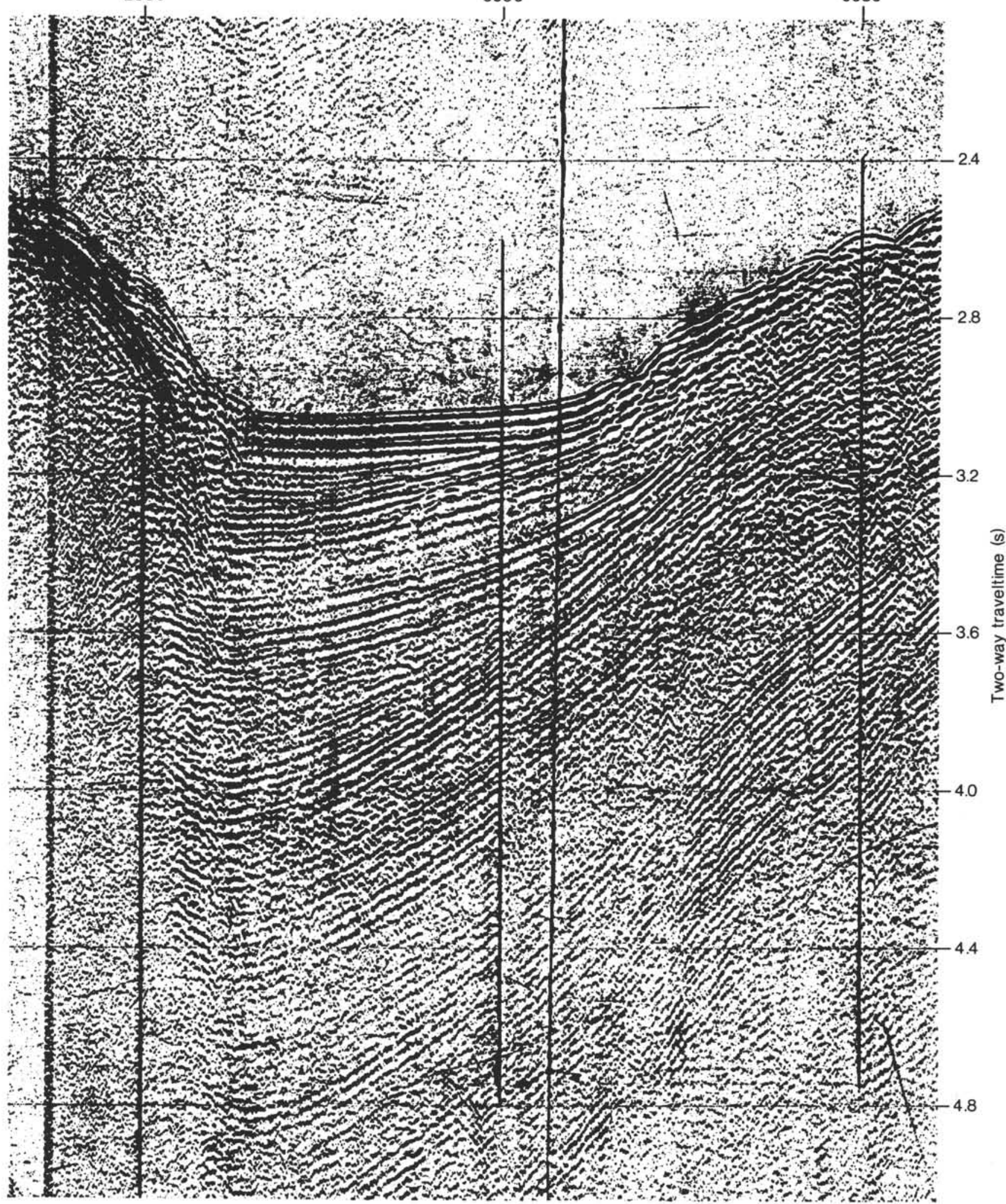

Figure 3. Seismic profile over Pigmy Basin (USGS Line 117, 5- and 40-in. ${ }^{3}$ air gun, 4-s sweep). 


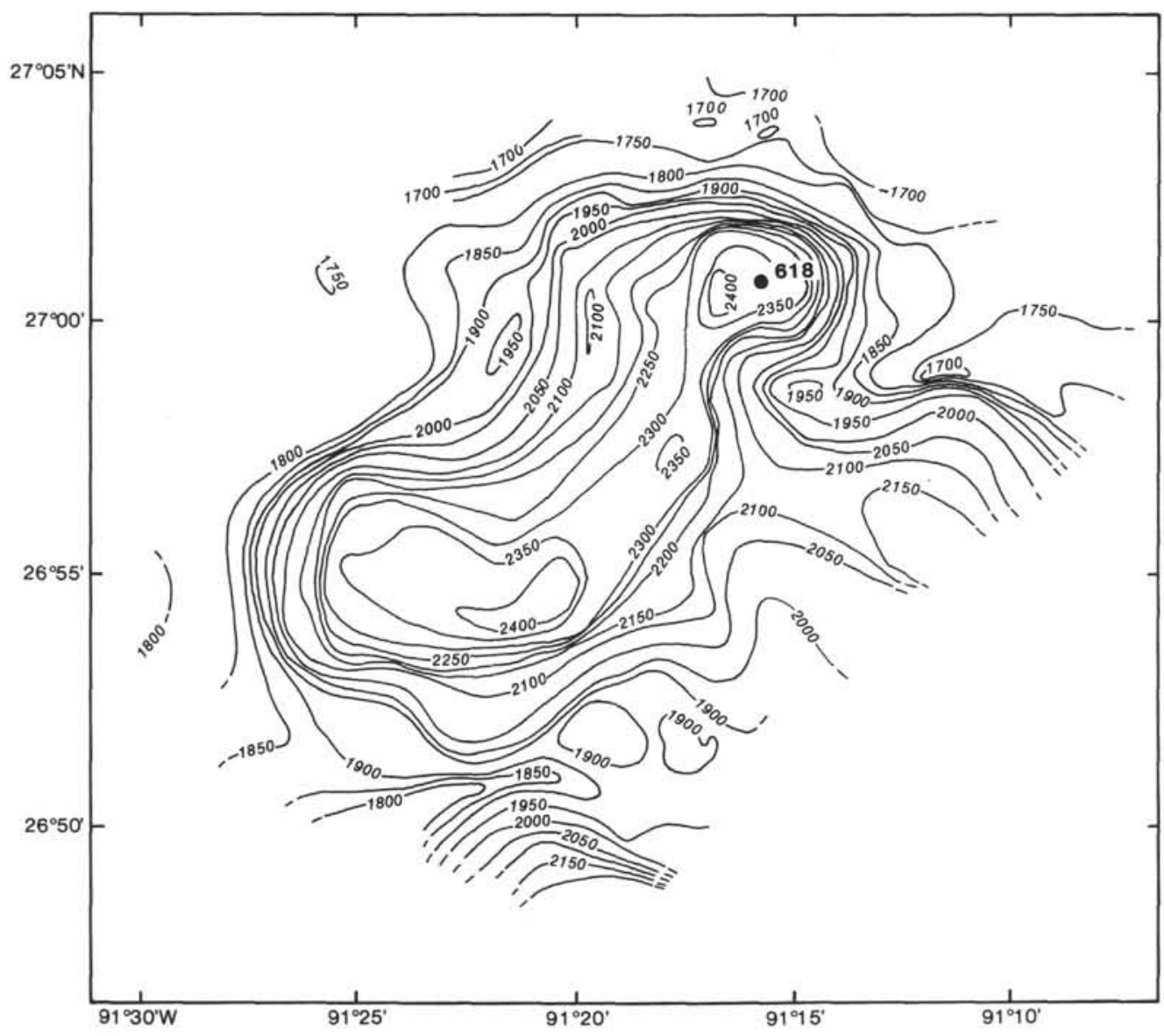

Figure 4. Bathymetric map of Orca Basin in meters (Feeley, 1982). Contour interval is $50 \mathrm{~m}$. 